\title{
A survey on the factors influencing lower-level 12 listeners' strategies use and proficiency level
}

\author{
Jing Xie \\ College of Foreign Languages, China Three Gorges University, Yichang of Hubei Province, China
}

Email address:

xiejing_ctgu@163.com

To cite this article:

Jing Xie. A Survey on the Factors Influencing Lower-Level 12 Listeners' Strategies Use and Proficiency Level. Education Journal. Vol. 2, No. 4, 2013, pp. 163-168. doi: 10.11648/j.edu.20130204.19

\begin{abstract}
This paper aims to identify the factors that cause EFL learners' lower listening proficiency level and how these factors influence students' performance in their listening process. Questionnaire and interview questions were designed to investigate 33 non-English majors and other EFL learners' strategy use and proficiency levels from four aspects: the learners, the language, the language environment and the teacher. Interviews were conducted and long-term observations carried out for further information. Results show that learners themselves are the main factor that influences their listening proficiency level, personality, language and the teachers' way of teaching also can have a negative influence on their proficiency level of listening. Thus teaching of English listening not only needs to take the training of the learners' listening strategies into serious consideration, but also requires teachers' modification of their teaching to suit the special requirements of students in various levels. The results may have pedagogical implications to facilitate both the college English teachers' teaching of listening and to improve the EFL learners' proficiency levels in listening.
\end{abstract}

Keywords: EFL Learners, Listening Proficiency, Lower Level, Influencing Factors

\section{Introduction}

The importance of listening was long overlooked in the past in the second language field though it was acknowledged that the listening process is "a complex skill that deserves the attention of learners and teachers alike" [1]. Though difficulties in $\mathrm{L}^{1}{ }^{1}$ listening is unavoidable, the types and the extent of difficulty differ, and much listening comprehension research has been conducted to investigate these differences. Some identified a list of the general factors [2] [3] [4], while others were on more specific factors such as background knowledge [5] [6], insufficient exposure to the target language and a lack of interest and motivation [7].

In China, the listening problems of EFL learners has also been widespread and neglected for a long period because it is considered not as important and useful as reading and writing, which explains why some students can read and write in English but are deaf in listening and dumb in speaking. In recent years, more research has been done on

\footnotetext{
${ }^{1}$ In this paper, 12 refers to English, which has been taken as the compulsory foreign language course in Chinese schools.
}

listening strategies in China. It is found that not all listeners are aware of what the various listening strategies are or how to use them. Also less attention has been paid to the less proficient listeners and the factors that might cause the difficulties in their listening practice. Hence, the author carried out the present study, with the purpose of identifying the factors that might cause EFL learners' lower listening proficiency level and how these factors influence students' performance in their listening process. Hopefully some pedagogical implications can be drawn for College English teachers and those less proficient listeners to facilitate their teaching and learning of English.

\section{Background of the Study}

The present study is stimulated by the author's own teaching experience and observation. In the university where the author works, the freshmen need to take part in the English Placement Test so that they can be graded into classes of corresponding levels according to their scores ---normal level and lower level (here "normal level" refers to English level of the students who has passed the English Placement Test with a score of equal or more than 60 out of 100 when they entered the university as freshmen. Those 
who got less than 60 points were referred as students of lower level English proficiency in this paper.). Students who failed in the test will study in the lower level English classes. Two years ago I began to teach students of lower level and came to realize the problems in their English learning, among which the students' lower listening proficiency level emerged as the most salient one. I started to look for causes.

\subsection{Classifications of Listening Strategies}

When a teacher is aware that students are not using the most efficient learning styles, s/he need to consider how best to introduce those learners to new styles. This is often done by encouraging the learner to develop a large repertoire of learning strategies [8]. To figure out the real causes of the lower level listeners' problems, it is necessary to find out how they deal with listening strategies in their L2 listening. Researchers have tried to find more effective listening strategies for second language listeners to help them acquire a high proficiency level in listening. In China, though less attention has been paid to the research on listening strategies, there are still some influential studies on listening strategies as well as on listening comprehension [9] [10]. Wang Yu's study, based on Wen Qiufang's classification of learning strategies [11], classified listening strategies into five groups: metacognitive, formal practice, functional practice, mother tongue reliance and social-affective strategies. Wang's study found that listening strategies had a positive effect on listening outcome. Also, effective and ineffective listeners showed differences in strategy use.

\subsection{Factors Affecting Listening Comprehension}

Boyle [3] classifies the factors that impact EFL listening comprehension in three ways based on a survey of Chinese teachers and students: 1) speaker factors: the linguistic ability of the speaker, the quality of the speech signal, the personality of the speaker, etc; 2) factors in the oral text: the complexity of the lexis and syntax, the degree of cohesion, etc; 3) listener factors, such as intelligence, memory, gender, motivation and background knowledge. In this article, the above factor are employed to analyze the factors that might influence the lower level 12 listeners' English listening proficiency level with some modifications as follows: the subjective factors like learner and teacher factor, and the objective factors like language and language environment factor. Discussion of the research results will be based on the division of the four aspects. Besides, I will take into consideration the subject's personal habit of practicing listening, which might influence their language learning and practice.

\section{Methodology}

\subsection{Participants}

Thirty-three non-English majors were investigated, involving 26 males and 7 females from the lower level
English listening class of China Three Gorges University (CTGU). Thirteen majors were covered, including PE majors and the others majors of science. Their English proficiency levels were relatively low and failed in the Placement Test organized by the university at the beginning of the new semester. They were graded into English classes for students of pre-intermediate level (relatively lower proficiency level compared with their schoolmates in the same year). It was shown by their test scores and noted from long-term observation that their listening ability was relatively weak compared with that of their reading, writing and speaking. At the time of the research they were all sophomores and had learned College English for almost four semesters. Some of them had been taught by different teachers in the past two years

\subsection{Instruments}

A questionnaire was designed based on Flowerdew and Miller's research[8]. The items in the questionnaire were classified into four main categories (factors that may cause low EFL listening proficiency): learners themselves, language itself, language environment and the teacher. Six questions were asked in the interviews following the questionnaire survey in order to gather further information.

\subsection{Data Collection and Analysis}

Step One: A listening test was given to the subjects (total number 33) without advance notice in order to reveal their true level of English listening proficiency. The test was adapted from the listening comprehension part of a CET-4 (the national College English Test-Band 4, the total of a CET-4 test is 710, including four parts: writing, listening reading and translating.) sample test designed in 2005 . The total score of the test was 249 . To make it easier to analyze, each score was transformed into 100 scales. The results are shown in the following table (Table 1).

Descriptive analysis was adopted in this study. The data was analyzed in the form of percentages and results are shown in figures or tables.

Table 1. The results of the previous CET-4 listening test

\begin{tabular}{cccccc}
\hline $\begin{array}{c}\text { Score } \\
\text { distribution }\end{array}$ & $\begin{array}{c}\text { Student } \\
\text { (person) }\end{array}$ & percentage & $\begin{array}{c}\text { Highest } \\
\text { score }\end{array}$ & $\begin{array}{c}\text { Lowest } \\
\text { score }\end{array}$ & Average \\
\hline$>=60$ & 2 & $6 \%$ & & & \\
$50-59$ & 2 & $6 \%$ & 67 & 21 & 38 \\
$40-49$ & 11 & $33 \%$ & & & \\
$<40$ & 18 & $55 \%$ & & & \\
\hline
\end{tabular}

Step Two: The questionnaire survey was conducted in one of the author's teaching classes. As organizer, she participated in the whole process of the survey. All the data-collecting sessions were carried out in the classroom during regular class-time in order to minimize the impact of the influence from the environment. All the participants completed the items as the teacher required. The teacher examined the answer sheets one by one when the questionnaires were collected. Finally 33 valid 
questionnaires (see Appendix I) were obtained.

Step Three: The results of the 33 questionnaires were evaluated and then ten students were chosen as representative to be interviewed according to their opinions and English-levels, which could reflect the whole situation to the greatest extent. The interview was conducted immediately after the questionnaires were analyzed. Some questions (see Appendix II) were intended to seek information about their listening habits and strategy use. Chinese was used as the means of communication, since both the participants and the researcher felt more comfortable and more able to express themselves in Chinese, thus allowing more data to be collected.

\section{Results and Discussion}

In this section, the factors that influence the L2 listeners' strategy use and proficiency level are described according to four categories: learner factor, language factor, teacher factor and language environment factor. Each factor's degree of influence is discussed in this part and possible explanations are sought to account for the phenomena. The subjects' background information was collected through the four items at the beginning of the questionnaire, including their gender, age, major and the result of their CET-4 examination (i.e. whether they have passed the national CET-4 or not last semester). It is shown that $28(88 \%)$ of the subjects have not passed the CET-4, only 4 (13\%) having managed to do so by the time of the research. That illustrates the current overall proficiency level of the subjects.

\subsection{Learner Factor}

In this category, five items are included in terms of the subjects' interest and confidence in learning English, their ability in listening comprehension, their personality and its influence upon their English learning. The results are shown in the following tables.

Table 2. The results of the three items on learner factor

\begin{tabular}{lccccc}
\hline Three items & No & Little & A little & Some & Great \\
\hline Interest & $2(6 \%)$ & $9(27 \%)$ & $14(43 \%)$ & $7(21 \%)$ & $1(3 \%)$ \\
Confidence & $2(6 \%)$ & $7(21 \%)$ & $13(40 \%)$ & $8(24 \%)$ & $3(9 \%)$ \\
Understanding & $1(3 \%)$ & $1(3 \%)$ & $19(58 \%)$ & $10(30 \%)$ & $2(6 \%)$ \\
\hline
\end{tabular}

Table 2 shows that only $3 \%$ of the subjects are interested in learning English and 9\% are confident about their ability to do so. $43 \%$ have merely a little interest and confidence; while $6 \%$ have no interest and confidence at all. The results show that the majority of the students are not very motivated in English learning. Even those who are motivated feel confused about how to make a reasonable plan to manage and monitor their own English listening process. That leads to their lack of confidence to learn the language well.

The degree of the students' understanding of teachers' words is not very high. More than $60 \%$ of the participants admit that they can understand nothing or just a little of what the teacher is talking about in class (when the teacher use only English to teach). Only 6\% say they can understand most of what their teacher says.

The influence of personality upon their English learning can obviously be seen in the results, which verified the findings in Wang Jialing's research [12], that is, the students' personality has an influence upon their foreign language learning. The students who are extrovert have better listening ability, while those who are introvert have little ability.

A learner's ultimate goal in learning English is decided to a large extent by the practical use of the language in their study and work. It demonstrates that most of the non-English majors' goal is functional, to employ Gardner and Lambert's [13] item instrumental motivation. The result in table 3 proved this. Nearly half of the students learn English in order to pass the CET-4 examination, and the number of those who want to use English as a tool in future job is just the same.

Table 3. The student's ultimate goal (motivation) in learning English

\begin{tabular}{lcc}
\hline motivation & No. & percentage \\
\hline Pass exams & 1 & $3 \%$ \\
Pass CET-4 & 15 & $47 \%$ \\
Find a better job & 1 & $3 \%$ \\
Use as a tool in future job & 15 & $47 \%$ \\
Other & 2 & $6 \%$ \\
\hline
\end{tabular}

However, lack of motivation and poor attitude do appear as major problems in learners' language learning process. In the interviews some students admitted that "they are too lazy to memorize new words which are essential and very helpful for listening", or "they don't like to do that", etc. According to the research's longitudinal observation, there are a few students who seem to be listening but only have a vague idea about what the speaker is saying. When they know that they did not understand fully, they were still not motivated to make it clear since listening is just finishing tasks and they do not have to treat it seriously. However, the truth is more positive than this. In almost ten years of teaching, I find that most students are strongly motivated to learn English in order to pass various exams or use it as a language tool. They try hard to listen even when there are plenty of difficulties to overcome. The problem is they are lack of the training of some necessary listening strategies and thus often feel helpless and anxious when dealing with all kinds of listening tasks.

\subsection{Language Factor}

In this part, when discuss about language, I mean either the learners' target language---English or their mother tongue---Chinese. For L2 listeners, sometimes the language itself poses an obstacle, as Table 4 shows.

Table 4. The subjects' apperception of English "listening"

\begin{tabular}{rlll}
\hline Not at little A little much much \\
\hline
\end{tabular}




\begin{tabular}{|c|c|c|c|c|c|}
\hline & all & & & & \\
\hline $\begin{array}{l}\text { Difficult } \\
\text { among }\end{array}$ & $4(12 \%)$ & $7(21 \%)$ & $10(31 \%)$ & $7(21 \%)$ & $5(15 \%)$ \\
\hline $\begin{array}{l}\text { other four } \\
\text { skills }\end{array}$ & \multicolumn{2}{|c|}{$11(33 \%)$} & & & \\
\hline $\begin{array}{l}\text { Important } \\
\text { to me }\end{array}$ & $3(9 \%)$ & $3(9 \%)$ & $4(12 \%)$ & $9(27 \%)$ & $14(43 \%)$ \\
\hline Different & $3(9 \%)$ & $2(6 \%)$ & $6(18 \%)$ & $13(40 \%)$ & $9(27 \%)$ \\
\hline $\begin{array}{l}\text { from L1 } \\
\text { listening }\end{array}$ & & & & $28(85 \%)$ & \\
\hline $\begin{array}{l}\text { Influenced } \\
\text { by } \\
\text { Language } \\
\text { differences }\end{array}$ & $2(6 \%)$ & $6(18 \%)$ & $8(24 \%)$ & $15(46 \%)$ & $2(6 \%)$ \\
\hline
\end{tabular}

Results show that $44 \%$ participants think "listening is very important for them". Some admitted in the interview they were not able to understand English well because "English grammar is too challenging", "there are too many new words in the listening materials", "it is hard to distinguish the speaker's pronunciation and speed of speaking", "many words in the material are hard to follow", "I've been poor in English since middle school", etc..

However, the impact of language is not always negative. $34 \%$ say that "listening is not (very) difficult among the four skills". During the interview, only four of the interviewees admit that listening is the most difficult skill in English. The other six think sometimes writing / reading / speaking seems to be a problem for them. But they also hold that "English language is very interesting", "English is a language easy to learn", "English will be very helpful for my future job", "the status of English is becoming more important in the world", to name just a few.

Differences between the students' mother tongue and the target language also make it harder to understand the latter. It is obvious that mother tongue use does have some effect on the learners' understanding of English. Among the five listening strategies mentioned in 2.1, the students tend to use mother tongue reliance strategy more often in their listening activities. Some of them are accustomed to translating what they hear into their mother tongue simultaneously in mind, which to some extent help them understand the listening materials better and lower the degree of anxiety. However, translating in mind takes too much time, which in turn hinders their understanding of the listening materials and do not benefit their real understanding of the target language.

The fact is that language itself is not enough to explain the learners' low proficiency level. It is not the language that causes all the difficulties in EFL learning. The real difficulty can be explained by the differences between the target language and the learners' mother tongue, and their Chinese way of thinking while listening to English.

\subsection{Teacher Factor}

Since listening is becoming more important than before in English language learning, how to enhance the learners' listening comprehension is what each English teacher is supposed to do. In this research, all the teachers, including the author, were Chinese who majored in English. Most of them have taught College English for years. I paid attention to teacher talk during my observations and found that most teachers try to adjust their language form and functions to facilitate the teacher-student communication. Especially when they talk to the less proficient listeners, they slow down, use simpler words and expressions and speak in a very clear way in order to help them understand better. Result of item 20 in the questionnaire (see Appendix I) shows that $69 \%$ participants like the teachers' way of teaching and interacting, among whom $22 \%$ say they like it very much, while $31 \%$ like it only a little. But that does not mean they do not experience anxiety when asked to do listening exercises. Questionnaire results show that more than $60 \%$ of the participants do experience the feeling of anxiety when being asked to do listening exercises in class.

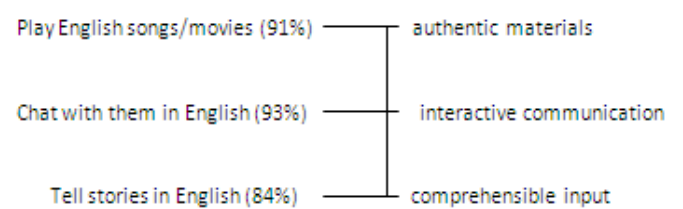

Figure 1. Students' preferences regarding their teacher's way of teaching listening

According to my classroom observation and talk with other teacher, most teachers tend to use more Chinese (the mother tongue) when teach lower level English students, which might have some negative influence to students' exposure to English. I was surprised to find out that even some lower level L2 listeners prefer teachers to use more authentic materials in class, because from the interactive communication with the teacher, they can gain more access to comprehensible information of the target language, which is helpful to arouse their interest and finally improve their listening ability.

Strategy use positively impacts self-concept, attitudes, and learning and attributional beliefs about personal control [14]. The regretful truth is that when teaching lower level students, teachers are not fully aware of the importance of listening strategies, so they seldom take time to train students to use some basic listening strategies consciously; while teaching high level students, they tend to pay more attention to the training of some useful strategies. Actually, compared with those high level learners who are usually better in using listening strategies, the lower level learners need intensive training on listening strategies more urgently than successful learners. Therefore, it is suggested that teachers need to raise their awareness of the importance of listening strategy to the lower level listeners and spend more time in such training to help students know how to learn effectively.

\subsection{Language Environment}

In this research, language environment refers to those real or virtual places where learners can have access to the target language. The textbook (New Horizon College 
English---Viewing, Listening and Speaking, Book 4) is still the main material used in listening class. The materials used in the textbook are all authentic, standard and diverse, which are presented as short and long conversations, passages either in the form of audiotapes or videos.

Table 5 shows that more than half of the students prefer to practice their listening ability through listening to English songs or watching English movies online. They explained the reasons in interview: "it's more interesting and gives me the chance to listen to Standard English", "it tells me how to use English in real life", and "English movies are wonderful and watching them makes me relax", "I enjoy listening when exposing to English songs or movies". Although few students say they can hardly follow the singers or speakers, they feel relaxed and find English interesting. The fun is what really counts for them. Thus, providing more relaxing and interesting supplementary materials and knowledge sounds an reasonable way to make the language learning environment more appealing and encouraging.

Table 5. Language resources and equipment used to practice listening

\begin{tabular}{lcc}
\hline & No. & Percentage \\
\hline Language lab/computer & 4 & $13 \%$ \\
Audiotapes/videotapes from the teacher & 5 & $16 \%$ \\
English songs/movies & 16 & $52 \%$ \\
Textbooks and tapes & 6 & $19 \%$ \\
Other & 4 & $13 \%$ \\
\hline
\end{tabular}

Findings in Table 6 demonstrate that most non-English majors have no access to native speakers and thus are not frequently exposed to the authentic language environment.

Table 6. Students 'frequency of exposure to native speakers

\begin{tabular}{lccccc}
\hline & Never & Sdldom & Sometimes & Often & $\begin{array}{c}\text { Very } \\
\text { often }\end{array}$ \\
\hline $\begin{array}{l}\text { Access to } \\
\text { native } \\
\text { speakers }\end{array}$ & $4(12 \%)$ & $15(46 \%)$ & $6(18 \%)$ & $7(21 \%)$ & $1(3 \%)$ \\
$\begin{array}{l}\text { Simply greet } \\
\text { them }\end{array}$ & $7(21 \%)$ & $15(46 \%)$ & $9(27 \%)$ & $1(3 \%)$ & $1(3 \%)$ \\
$\begin{array}{l}\text { Communicate } \\
\text { more with } \\
\text { them }\end{array}$ & $6(18 \%)$ & $16(49 \%)$ & $8(24 \%)$ & $2(6 \%)$ & $1(3 \%)$ \\
\hline
\end{tabular}

Besides the textbook used in class, the language lab (a place where students can have free access to the online English classrooms and all kinds of English learning materials) enable students to be exposed to broader language learning environment. However, only a small number of the participants tend to use the lab effectively to practice listening. Some say in interview that they do not know how to manage their study in the lab. This indicates that students need teachers' guidance about how to manage their listening activities in such kind of language environment.

\section{Conclusion}

In this article, I analyzed four factors that might influence the lower level listeners' strategy use and proficiency level. The major findings of this study are as follows: 1) The learner factor is the most influential among all the other factors in that learners' motivation, personal background, learning experience, personality, interest in the language they are learning, etc. impact their strategy use and proficiency level. Their low proficiency is to some extent due to their attitude towards English and the time and effort they are willing to spend in learning and practicing it. Students' personality has some influence upon their listening practice: extrovert students have better listening ability. 2) Both the teacher and learners need to raise their awareness of the importance of strategy use in English listening process and take more time to train the strategy use. 3) Regardless of the listeners' low 12 levels, EFL teachers need to use more authentic materials in class and talk with students in the target language, in that such talk is usually related to students' own life experience and thus can arouse their interest greatly and help improve their understanding and confidence.

The implication of knowing about the learners' listening preferences is that teachers may be able to adapt their teaching methods to suit specific groups of lower level English learners. Teachers also need to know the students well and stimulate their willingness of learning English by arousing their awareness of the metacognitive strategies in listening, especially the strategies of self-management, self-monitoring and self-evaluation. This may help the learners' become aware of how to learn, which appeared to be the significant factor distinguishing the successful from the less successful listener [15].

Limitations are inevitable since the size of the sample limits the generalizability of the results. Further studies can be done among larger numbers of participants, and more types of data can be collected. Hopefully this study may stimulate teachers to improve less proficient learners' listening proficiency, which obviously needs much efforts from both teachers and students. Therefore, it is necessary to carry on further studies focusing on other factors like the students' personal background and learning experiences of English, etc.

\section{References}

[1] Oxford, Rebecca L. "Research update on Teaching L2 Listening" [J]. System, 1993, 21:210.

[2] Tinkler, T. "Learning to teach listening comprehension". ELT Journal, 1980. 35(1), 28-35.

[3] Boyle, J.P. "Factors affecting listening comprehension" [J]. EFL Journal, 1984. 38: 205-211.

[4] Flowerdew, J, Miller, L.. "Student perceptions, problems and strategies in L2 letures. RELC Journal, 1992, 23:60-80.

[5] Markham, P., Latham, M.. "The influence of religion-specific background knowledge on the listening comprehension of adult second language students". 
Language Learning, 1987, 37:157-170.

[6] Long, D. R.. "What you don't know can't help you: an exploratory study of background knowledge and second language listening comprehension". Studies in Second Language Acquisition, 1990, 12: 65-80.

[7] Goh, C.. "A cognitive perspective on language learners' listening comprehension problems." System, 2000.

[8] Flowerdew, John \& Lindsay Miller. Second Language Listening: Theory and Practice [M]. Cambridge University Press, 2005/2006(2nd ed.).

[9] Zhou, Qijia. "Influence of Learning Strategies upon English Listening Comprehension---An Investigation on the Learning Strategies of English Listening and the Analysis of Its Results" [J]. Journal of PLA University of Foreign Languages, 2000 (3).

[10] Wang, Yu. "A survey on the non-English majors' listening strategies" [J]. Foreign Language World, 2002, (6), serial No. 92.
[11] Wen, Qiufang. Applied Linguistics: Research Methods and Thesis Writing [M]. Foreign Language Teaching and Research Press, 2004.

[12] Wang, Jialing. "The Relationship Between Learners' Personality Traits and EFL Learning" [J]. Journal of Xi'an International Studies University, 2007 (2).

[13] Gardner, R. and W. Lambert. 1972. Attitudes and Motivation in Second Language Learning. Rowley, Mass.: Newbury House.

[14] Borkowski, J.G., M. Carr, E. Rellinger, \& M. Pressley. Self-regulated Cognition: Interdependence of Metacogntion, Attributions, and Self-esteem. In Jones, B.F. \& Idol, L. (eds), Dimensions of Thinking and Cognitive Instruction, 1990, 53-92. Hillsdale, NJ: Lawrence Erlbaum.

[15] Vandergrift, L. "The Comprehension Strategies of Second Language (French) Listeners: A Descriptive Study". Foreign Language Annals, 1997. 30, 3: 387-409. 